\title{
Nanotechnology in food safety and quality assessment: potentiality of nanoparticles in diagnosis of foodborne pathogens
}

\author{
Maša PRIMEC \\ University of Maribor, Faculty of Agriculture and Life Sciences, Pivola 10, 2311 Hoče, Slovenia
}

\begin{abstract}
A rapid microbial detection in different biological and environmental material is a key of preventing several foodborne diseases. By implementing nanotechnology into food safety sector, a great step towards successful, reliable and sensible detection methods of foodborne pathogens has been achieved. Therefore, the aim of this review was to illustrate some of the principal functions of nanotechnology-based techniques, used for microbial detection in the last few years. Regarding consumer's health, the review also discusses the question of safety, concerning human exposure to nanomaterials (NMs). Due to their different composition-unique properties, such as greater penetrability, reactivity and high surface to volume ratio, NMs have been coupled to several biomolecules and integrated in special system devices, resulting in improvement of sensitivity in transmitting biological signal informations in a shorter time. Among all the NMs, gold, magnetic and fluorescent nanoparticles (NPs) have been widely used, also in microbial diagnosis. Despite the success of linking nanotechnology to detection of foodborne pathogens, the exposure to various NMs could also be a matter of potential risk to human health, although conclusions still need to be definitely proven.
\end{abstract}

Kew words: nanotechnology, food safety, nanoparticles, diagnosis, foodborne pathogens

\section{INTRODUCTION}

More than 250 known diseases are caused by different potent transmitting agents, merely coming from food or food products (Arora et al. 2011). The whole concept of food safety indeed aims to assure a high level of food safety, animal health, animal welfare and plant health through coherent farm-totable measures and adequate monitoring, while ensuring the effective functioning of the internal market. Controlling and monitoring each individual step in "agri - food - industry market" chain is the first and very important step towards the accomplishment of preventing different foodborne diseases.

Foodborne disease is an important source of expense, morbidity, and mortality for the whole society. Therefore, an ideal detection method to prevent and control the illness, mainly caused by foodborne bacterial pathogens, some chemical substances and natural or chemical toxins, is needed. Reducing the occurence of foodborne diseases through the use of fast, cost - effective, sensitive and accurate detection method (Billington et al. 2014) is an urgent need for early diagnosis of infectious diseases. Moreover, rapid microbial detection from water, food, environmental and clinical samples is indispensable for both public health and security perspectives (Dutse and Yusof, 2011, Mairhofer et al., 2009).

Potential applications of nanotechnology in biomedicine are broad, using nanomaterials for the treatment as well as diagnosis at the molecular level (Kim et al. 2010) and developing nanotechnology-based assays for sensitive and early detection of microbial agents or their products (Liu 2006, Kim et al. 2010, Vashist 2013). In particular, there is enormous interest of using nanobiotechnology in developing novel nanoparticle-based biosensors and assays for microbial detection.

The aim of this review is to provide some informations about advancements made in last few years in the field of nanotechnology-based assays and biosensors for microbial detection. The review discusses also some critical points 
about safety of nanotechnology in food production and industry in terms of consumer health.

\section{DETECTION OF FOODBORNE BACTERIAL PATHOGENS}

The impact of foodborne disease is a significant economic and clinical issue, although many recent advances in food safety. Generally, foodborne diseases are caused by the consumption of food or water contaminated with pathogens or their toxins, which include mostly bacteria, viruses, fungi and parasites (Zhao et al. 2014). Listeria monocytogenes, Escherichia coli O157:H7, Staphylococcus aureus, Salmonella enterica, Bacillus cereus, Vibrio spp., Campylobacter jejuni, Clostridium perfringens and Shiga toxin-producing Escherichia coli (STEC) (Oliver et al. 2005, Zhao et al. 2014), Clostridium botulinum, Yersinia enterocolitica and Coxiellaburnettiare common foodborne pathogens, which are responsible for most of the foodborne disease out-breaks. Moreover, foods such as fruits, vegetables and ready - to - eat products, which are consumed without any further treatment, may be also a source of foodborne pathogens (Chung et al. 2010, Lee et al. 2014). Consumption of raw or undercooked foods such as seafood, meat and poultry (Wingstrand et al. 2006, Rosec et al. 2012, Omurtag et al. 2013) may also potentially lead to foodborne diseases.

Thus, it is essential to analyze the food for the presence of foodborne pathogens in order to ensure safety and to minimize the occurance of foodborne diseases (Law et al. 2014). In this regard, developing an ideal detection method has been so far a strong scientifical issue. Ideally, it would be desirable to detect even a single pathogen present on or in a food sample. The conventional methods, which are mostly culture-based methods, tend to use an enrichment step, in which low numbers of target cells are encouraged to multiply to detectable number. However, that means 1-2 days more time spent in total analysis time (Billington et al. 2014). That is time consuming. The conventional methods are laborious, as they require a lot of media preparation, inoculation of the plates and colony counting (Mandal et al. 2011). Furthermore, they may be limited by their low sensitivity, especially when concerning false negative results (Lee et al. 2014). On the other hand, the conventional methods are usually inexpensive and more or less simple (Law et al. 2014). Biochemical and serological testing for the identification of bacterial agents have also been used for almost a century.

Recently, different rapid methods with high sensitivity and specifity have been developed to overcome the limitation of conventional methods for the detection and identification of foodborne pathogens. Rapid methods are more specific, sensitive, time-efficient, labor-saving and able to reduce human errors (Mandal et al. 2011). They may be generally categorized into nucleic acid-based, biosensor-based and immunological-based methods and provide various advantages, but also limitations for the detection of foodborne pathogens as reviewed in Law et al. 2014.

\section{Nanotechnology in detection of microbial agents}

Recent research in nanotechnology-based strategies for microbial detection has produced highly fascinating and promising results. Among several special properties of nanomaterials, characteristics such as greater penetrability, reactivity, high surface to volume ratio, and quantuum properties due to their size, allow the use of less material and new or more efficient chemical and physical reactions in comparison to larger scale materials (Kalpana Sastry et al. 2013). Moreover, the development of the automated and miniaturized system has offered great advantage, especially when used in field sectors, requiering less complicated protocols (Gabig-Ciminska 2006). The most promising advancement, concerning rapid, sensitive and cost-effective microbial detection, are disposable stick tests, based on gold NPs and described in more details below (Syed and Bokhari 2011). Furthermore, merging of nanotechnology inbiosensing has improved sensitivity and detection limits of biological events, microbial toxins, bacterial and viral agents (Doria et al. 2012).

\section{Nanodiagnostic approaches in detecting microbial agents}

Nanodiagnostic procedures have been found as future promising tool in detecting and sensing at single cell level. Moreover, nanotechnology-based assays for microbial detection and identification (determination) have the ability of fast, label free, highly sensitive testing, with the "onsite utility option" (e.g. lab on the chip assay, see later below) (Chen et al. 2007, Jain 2007).

Nanomaterials coupled to biomolecules, such as antibodies, nucleinic acid probes, aptamers, can sense and transmit biological information in a short time, resulting as promising material for biosensing applications (Kim et al. 2010).

\section{Biosensors}

Biosensors are analytical devices used to detect unknown biological agents or study biological events (Syed 2014). These devices use specific biochemical reactions, mediated by isolated enzymes, immunosystems, tissues, organelles or whole cells (usually called bioreceptors, which recognize the target analyte), to detect chemical compounds, mostly by electrical (electrochemical), thermal or optical signals (Thakur and Ragavan 2013). In fact, after specific binding of bioreceptor - target analyte occures, an alternation in one or more physiochemical properties is caused, resulting in detection by a proper transducer. The later is capable of converting a specific biochemical reaction into a measurable signal. Based on nanoparticles (NPs), implemented in biosensors (e.g. gold, fluorescence and magnetic or a combination of all (nanocomposite)), a measuring signal could be obtained and determined, due to their specific optical, fluorescence and magnetic properties, respectively. 
The determination is performed by using optical (absorbance or luminiscence), electrochemical (voltage or current) and mechanical (magnetic resonance) transducing measurements (Koedrith et al. 2015).

Biosensors have been also widely used in food safety area (Thakur and Ragavan 2013), especially in detection of foodborne pathogens (Arora et al. 2011, Law et al. 2014). Diagnostic of pathogens, especially in the field, that needs systems and test kits, which are sensitive, quick, portable and cost-effective. The NPs are indeed very sensing materials, due to their strong physical enclosure of electrons at nanoscale. Moreover, their small size correspondes to high surface-tovolume ratio, enabiling and improving binding and detecting (signaling) properties. In fact, their direct relationship to the size, composition and shape allow their physical properties to be costume-made (Wang et al. 2010). Thus, NPs act as signal reporters in biosensors and therefore increase significantly a signal and reduce the time of target cells to be detectable. Nevertheless, the detection techniques with NPs requires a testing instrument such as spectrophotometer, fluorescence microscope, luminometer etc. (Koedrith et al. 2015).

The possibility of using nanostructures in bacterial detection that, either incorporate biological elements or are entirely biological in origin (for example the use of phages, viruses that infect bacteria), have also been reviewed (Billington et al. 2014).

\section{Microfluidic assays or lab-on-a-chip (LOC)}

LOC are small devices that integrate one or more laboratory functions (single or multiple lab processes) on a single chip of a very small size (milimeters to square centimeters). They are part of a subset of microelectrochemical systems (MEMS) - a technology of very small devices. The size of MEMS devices ranges from 20 micrometers to a milimetre, usually consisting of a microprocessor, which processes the data, and microsensors, which interact with the environment. There are basicly two components included in MEMS devices, the electrical and mechanical one. These two devices have been lately extended into optical, radio-frequency and nanodevice applications. Due to that, the generation of microoptoelectrochemical system, radiofrequency system and nanoelectrochemical system has emerged, respectively. The application of MEMs devices is broad, from display technologies to sensor systems and optical networks. Their small size and weight is the most important advantage, which allow the systems to be miniaturized (Walder, 2008). LOC can be also reffered as microfluidic assays and the main advantages, which are speed, sensitive and accurate diagnosis from small fluid volumes less than picoliters, have been also used in detection of pathogens (Dutse and Yusof 2011). The advantage of a size reduction means a reduced consumption of reagent. In fact, the name of lab-on-chip device derives from the capability of integrating separation and monitoring technique within a single, portable device, which is very important in detection of pathogens from environmental samples or in clinics. The whole LOC device is based on a variety of operations, from sample pre-treatment to signal detection, obtained from optical (fluorescence, predominatelly) and electrochemical sensors (Mairhofer et al. 2009). Moreover, the enchanced sensitivity of a LOC device in detecting pathogens is its continuous injection of bacterias, resulting in their accumulation inside the chamber of a chip microfluidic device (Boehm et al. 2007). LIU et al. 2006 have developed an integrated miniaturized portable device for simultaneous detection and genotyping of a number of pathogenic bacterial species, based on nucleic acid hybridization process.

The improved sensitivity in microfluidic biosensors devices is also obtained by labelling NPs to antibodies or DNA, which results in efficient and easier immobilization on modificated transducers. For instance, Varshney and Li 2007 used magnetic nanoparticles, labelled to anti-E. coli antibody, coupled to microelectrode, to obtain a better immobilization of the bacteria with magnetic field. Moreover, Salmonella typhimurim has been detected by using a microfluidicbased nanosensor with magnetic beads and quantuum dots (QDs) as a fluorescent label (see later for explanation). AntiSalmonella-antibodies were coated with magnetic beads, whereas separated bacteria cells were labelled with anti-body conjugated QDs to form a sandwich complex. The enchanced and faster pathogen detection of this assay is a result of a better target concentration, due to magnetic beads, and a better signal, due to particular properties of QDs (Kim et al. 2015).

\section{Nanoparticle-established assays}

Nanoparticle-established assays usually consist of a recognition element, such as nucleic acid probe, antibody, enzyme, aptamer or some other biomolecules, that bind to specific ligand (such as bacteria, virus, toxin etc.), and NPs for the transduction of this biological event into a measurable signal (an optical reporter).

NPs offer higher surface to volume ratio, which increases sensitivity in the biomolecule detection at a smaller size. In fact, once coupled to the biomolecule, their sensitivity and transmition of the biological information occurs very fast. Moreover, coupling with target molecules can provide a significant effect on their physical and chemical properties, thereby providing a mode of single signal transduction. Thus, their optical, electronic or magnetic properties (see explainationbellow), depend on their core materials, their size and shape. NPs' properties can vary within their surrounding chemical environment, resulting in being able to undergo surface modification by binding different small organic ligands and large macrobiomolecules. Gold, magnetic and fluorescent NPs are widely used in diagnostic applications, for instance in microbial diagnostic (Agasti et al., 2010, Liu, 2006, Syed and Bokhari, 2011). Moreover, Oh et al. 2011 used polymeric nanoparticles in diagnostic assay for detection of Antrax, though their greater potentiallity comes more from being a potent vector for vaccine delivery, targeting especially cancer and infectious diseases (Bolhassani et al. 2014). 


\section{Gold NPs}

The syntesis of gold NPs is nowdays well known in aqueous or organic solvents. Either using the gold NPs in aqueous or organic solutions, a stabilizing agent (surfactant) aroud its core is essential, in order to perform theircolloidial stability. The stability is obtained, either by adsorbtion, or by chemical boundery of the proper surfactant onto the surface of the gold NPs. The surfactant has to be tipically charged, so that the equally charged NPs do not undergo aggregation. In this way, by choosing different surfactants, it is possible to adjust different properties of the gold NPs (Sperling et al. 2008).

Gold NPs exibit a broad spectrum of applications among NP based assays for microbial detection and identification. One of the important properties, that make the gold NPs an ideal material to be used in the detection of biomolecules at lowest concentration, is their size dependent physiochemical properties (Syed and Bokhari 2011). In fact, small size NPs $(2-15 \mathrm{~nm}$ in diameter) are used merely in immunohistochemistry, microscopy and biomarkers, medium size NPs (20-60 $\mathrm{nm}$ diameter) are used in environmental detection (concerning also food pathogens), purification, drug delivery, biomarkers, chemical sensors and DNA detection, and large size NPs (80-250 nm diameter) are used in forensics, electronic devices, manufacture, optical mammography. Another advantage of gold NPs to the other inorganic NPs is their biocompatibility with human cells and ease bioconjugation with molecules like DNA, RNA, antibodies, peptides (Shah et al.2014). Their optical properties, inertness in biological fluids and stability make them one of the most potent materials used in nanodiagnostics (Syed and Bokhari 2011). The optical properties can be easily controlled by varying their size, shape and composition, which turns out in a range of colours (brown, orange, red purple), as the core size extens from 1-100 $\mathrm{nm}$ in diameter, and results in distinct light scattering properties (Rosi and Mirkin 2005). Indeed, an interesting property of gold NPs, which has upgraded the sensitivity of the nanoparticle-based optical biosensors to those without them, is their plasmon resonance frequency (510-530 nm for NPs of 4-40 nm diameter). Namely, metal NPs, when excited with electromagnetic radiation, produce intense absorbtion due to the oscillation of surface electrons. The frequency of the mentioned oscillation is in resonance with the incident light. The intense colours, produced from NPs, occure due to the appearance of the resonance frequency or, so called, surface plasmon band, which lies in the visible part an ofelectromagnetical spectrum. This optical property (surface plasmon resonance - SPR) can be measured by absorbtion and scattering spectroscopic technique. Thus, molecules absorbed onto the surface of, for instance gold NPs, can therefore induce changes in electron density on their surface, causing the shifting in the SPR band and resulting incolorchange (Liz-Marzán 2006). The SPR property depends on the particle size, shape, material and the distance between the particles. Namely, the binding of one molecule to the metal (gold) surface of a nanoparticle, may change the plasmon resonance directly, which can be observed by their scattered light in dark field microscopy. Moreover, if the average distance between the gold NPs is reduced (if the aggregation occures), the effect of SPR frequency is dramatically changed, resulting in a change of colour from red to violet/blue. The colour change can be used for colorimetric detection of an analyte (Yeh et al. 2012, Ali 2014, Koedrith et al. 2015). Gold NPs have also a unique property of quenching the fluorescences of many fluorophores (Sperling et al. 2008), when appearing in close proximity to their surface, which results in a low or no fluorescence signal detection (see later for explanation).

Gold NP have been also used in immunochromatographic strip biosensors (as disposable dip stick tests) and for sensitivity enhancement of many diagnostic assays (Halfpenny and Wright 2010, Syed and Bokhari 2011). These assays are based on membrane chromatography and utilize colloidial gold NPs, coupled to the specific antibody, which targets the antigen, presented in the sample. If the binding occurs, an antigen-antibody-NP-complex is formed and the binding of the second capture antibodies to that complex, give rise to a red colour due to the aggregation of the colloidial gold NPs. Moreover, strips have been developed also for detection of antibodies in a sample, by capturing it with inactivated microbial antigens (Cui et al. 2008) and furthermore, for some pathogens like bacterias (Huang 2006) and viruses (Peng et al. 2008). The advantage of these strips is their quick, efficient, cost effective and simple diagnosing, without the need of further detection instruments. Nevertheless, there is still a problem inavailability of diverse specific antibodies (Syed and Bokhari 2011).

Assays, based on colorimetry have been also performed forthe detection of microbial DNA using gold NPs, conjugated with specific DNA/RNA probes (single strand), which are complementary to the microbial nucleic acid sequences. The binding on the complementary nucleinic acid (hybridization) results in aggregation of gold NPs and visualisation occurs with naked eyes (Gill et al., 2008, Ray et al., 2007).

One of the properties of gold NPs, that enchance again the sensitivity of the electrochemical biosensors in diagnostic of foodborne pathogens, is their redox activity. Electrochemical biosensors have the ability to transduce a biological event into an electronic signal, which can be measured (e.g. current, voltage). They are so far the most commonly used and sensitive types of biosensors, utilized also in detecting foodborne pathogens (Syed and Bokhari 2011, Law et al. 2014). According to the type of electrochemical property to be measured, that is changes in current, impedance, voltage and conductance, they can be classified into several types (Zhang 2013). One of the examples of gold NPs implementation into electrochemical biosensors is their conjugation on the single strand DNA, which is complementary to microbial DNA of an analyte. The better binding of the DNA-gold NPs on the transducer surface (an electrode, which is usually gold), the more sensitivity of the electrochemical biosensor is obtained (Zhang 2007). Gold NPs in this case mediate direct transfer of electrons in redox reaction. Their binding onto the electrode surface results in higher currents, due to their larger surfaceto-volume ratio and their close contact to the proximity to the center, which consequently facilitate the electron transport. Another example is the use of gold NPs, conjugated to the redox enzymes, which can specifically oxidize or reduce the detected analyte as their substrate in the reaction. After binding of the analyte, the enzyme-gold NPs is immobilized on the surface of a gold electrode, which eventually enchances the current signal (facilitates the electron transport) (Sperling et al. 2008). 


\section{Magnetic NPs}

Magnetic NPs are one of the commonly used NMs, which can be manipulated with the magnetic field. In general, their aredevided into two types. One type are metallic magnetic NPs, ( $\mathrm{Fe}, \mathrm{Ni}, \mathrm{Co}$ ), which have the disadvantage to quickly oxidize and thus not very appropriate in preparation of ferrofluids (colloidal mixture of magnetic nanoparticles, suspended in an organic or water fluid), although carring better magnetic properties (Shokrollahi 2013). The other type are magnetic NPs of different types of iron oxide (magnetite, maghemite) and other ferrites. Not only their magnetic properties, but also their size, high stability in suspension, infiltration and interaction on the cellular and molecular level, give rise to their applicability also in biomedicine science.

It has been shown (Gupta and Gupta 2005), that the size between 10 and $100 \mathrm{~nm}$ in diameter is most applicable in biomedicine field, due to higher effective surface area, which makes the attachment of different ligands easier. Moreover, the size is also important to obtain a phenomenon, called paramagnetic property. The paramagnetic property can be accomplished, for instance, with magnetite NPs (smaller than $20 \mathrm{~nm}$ ) and maghemite NPs (smaller than $15 \mathrm{~nm}$ ). In those two cases, the magnetization directions are subject of thermal fluctuation at room or biological temperatures, that is, without an external magnetic field. Thus, their magnetization value is randomized to zero, which additionally prevents the agglomeration of the magnetic NPs, as they act as not possesingany magnetic capabilities. On the other hand, when the magnetic NPs are placed in a magnetic field, they act as normal magnetic materials. Because of these two properties, these kind of magnetic NPs create a superparamagnetic phenomenon (Xu and Sun 2013).

The stability of the magnetic NPs is merely due to their core and shell structure, which are indeed the main challenge for many scientists. The metallic core posess highest saturation magnitization, but are toxic and, as mentioned before, extremely sensitive to oxidation. On the other hand, more or less better stability (because of less sensitivity to oxidation), is obtained with ceramic cores (iron oxides, ferrites - cobalt, mangan, zinc). The other parameter, which plays an important role in high stability of magnetic NPs, istheir shell (surface), composed of various kinds of coating materials (surfactants), such as organic materials (polymers), inorganic metals (gold, platinum), or metal oxides (aluminium, cobalt), inorganic silica,..(Karimi et al. 2013). For instance, the incapsulation with gold, apart from stability and biocompatibility, provides further functionalization, that is a surface plasmon property (optical detection), strong absorption in near infrared spectrum and sensitive magnetic resonance image response. Better stability and multifunctionality can be obtained also with silica encapsulation, in particulary to preserve the magnetic properties of magnetic NPs or optical properties of QDs (see below the explanation), if used together (concentration / traceability property). Moreover, magnetic NPs, encapsulated with silica can be used as carrier for anticancer drugs and fluorescence molecules (therapy / traceability property) (Xu and Sun 2013). Apart from stabilization, the shell prevents magnetic NPs to agglomerate (aggregate) as they tend to do that, because of the magnetic force between them. Moreo- ver, the shell gives them biocompatibility, a property, which is very important in their in vivo applications. In that case, the magnetic nanoparticles can play an "undercover foreign body", which our body detects as "not foreign". Furthermore, biocompatibility, large surface-to-volume ratio and chemical reactive biomolecules provide a lot of chemically-active sites for biomolecule conjugation, responsible for their functionalization (Tartaj et al. 2003, Gupta and Gupta 2005, Shokrollahi 2013).

The application of magnetic NPs in diagnostic of foodborne pathogens is scarce. Nevertheless, their usage has been merely limited to assist separation, purification and concentration of different biomolecules, including those from microbes or complex matrices (Liu, 2006, Huang et al. 2010). In fact, separation of a desired biological part or fraction from the native environment (complex food sample, blood) can be accomplished, due to the magnetic property of biocompatible NPs. The process involves anindirect labelling or tagging of the desired biological target through a link (an antibody, hormones) with magnetic particles (size dependent - NPs, microbeads) Furthermore, a concentration and purification of the complex target-link-magnetic particleswith fluidbased magnetic separation device is obtained(Pankhurst et al. 2003). Thus, the chemical modification (coating with dextran or other biocompatible molecules) on the surface of the magnetic nanoparticle allows the NPs to bind on the link and assures their stability. After a specific binding of the link-magnetic NPs to the target occurs, the whole fraction is captured (immobilized) and concentrated on the magnetic device (magnetic column or microspheres, in case of larger targets and larger particles). The negative fraction (where no specific binding occurred) passes through. Surprisingly, Huang et al. 2010 used specific amine-functionalized magnetic nanoparticles (AF-MNPs) to directly capture and remove several pathogens from different samples with an external magnet and without any further labelling with affinity biomolecules (links).

Another important application of magnetic NPs in detecting microorganisms is their implementation in biosensors (Kaittanis et al. 2007, Maalouf et al. 2008, Koh and Josephson 2009). Kaittanis et al., 2007 have demonstrated the higher sensitivity and specifity properties of immunomagnetic relaxation nanosensors, compared to old, culture techniques in detecting a pathogen from a sample. With the mentioned nanosensor, the detection of Mycobacterium avium spp. paratuberculosis(MAP) was performed. The nanosensors used in this assay were prepared with superparamagnetic iron oxide NPs, conjugated to antiMAP antibodies and were incubated with the sample (milk with MAPs). The anti-MAP antibody-NPs complex, which can be in either dispersed (not bound to MAPs) or clustered (assembled, bound) state, due to its binding to bacteria, can consequently swich from one state to the other, as a result of factors such as temperature, $\mathrm{pH}$ and a high concentration of competing analytes (bacteria in that case). The magnetic relaxation switch phenomenon is therefore the principle of the detection mechanism of these kind ofnanosensors. With a change of aggregation (clustering) - swiching state,the change in the spin - spin relaxation time (T2) of the solution's water protonsoccures. In fact, T2 relaxation refers 
to the progressive dephasing of spinning dipoles, following the $90^{\circ}$ pulse as seen in a spin-echo sequence due to tissueparticular characteristics (inhomogeneities; in our case solution of target bacteria). These characteristics primarily affect the rate of moment of protons, mostly found in water molecules (solutions) (Levitt 2008).The mentioned effect (change of state) is observed in nanosize magnetic particles (5-300 $\mathrm{nm}$ in diameter) as a decrease in T2 relaxation, that is, a result of the inhomogeneities in magnetic field, produced due to the binding processes of NPs complex to the target. At the end, detectability of the specific analytedue to changes in T2 is measured. Thus, the less bacteria is in the solution, the higher the ratio of available bond NPs complex is obtained (more assembled states), resultingin higher values of T2 changes that are furthermore detectable and quantified. On contrary, as the concentration of bacteria in solution increases, the binding of NPs complex comes to a more disperse-like state (NPs have to disperse among all bacteria), which causes smaller changes in T2 values. In fact, the NPs aggregation and the size range of the mentioned aggregates depends on the type of analyte and analyte concentration (Koh and Josephson 2009). In the work of Kaittanis et al. 2008, detection of pathogens is performed by magnetic relaxation phenomenon. They used dextran-coated iron oxide nanosensors, supplemented with Concavalin A (Con A, lectin: carbohydrate - binding protein, which has a great affinity to bind carbohydrates on the bacteria surface), or silica-coated iron oxide nanosensors, directly bound to Con A, for the detection of Escherichia coli O157:H7. Lee et al. 2009 have also implemented the superparamagnetic property and magnetic relaxation spin-spin phenomenon of magnetic NPs to detect and concentrate Mycobacterium tuberculosis in a microfluidic (portable on chip bacterial detection, see bellow general explanations) chamber and measured itwith nuclear magnetic resonance.

\section{Fluorescent NPs}

The use of fluorescence to detect different biological events have helped a lot in enchancing sensitivity inanalyzing different biological proccesses, especially those that cannot be detected with naked eyes. Different molecular transducers (fluorophores) have the capability to transfer energy from chemical, physical or biological events into specific light thatcan be detected. Moreover, fluorophores can act also oppositely, that is, they can create signals, which can be transffered afterwards through different events, resulting in controlling specific processes. Since many years, different organic dyes, fluorescent proteins, have been used for medical and biological purposes with simple, quick and non-distructivemethods. To overcome some limitations of classical dyes (e.g. short lifetime, poor detecting sensitivity), the use of NPs-based detection methods have made one progress in incresing sensitivity (higher signal intensity), stability and capability of multiplexing, that is, combining several fluorophores, by coupling them to different particle matrices. Due to that, the combination of nanosized particles and fluorescence has become a good alternative to study the diversity and versatility of biological events (Hötzer et al.
2012, Ruedas-Rama et al. 2012).

A major concern in bioconjugation (labeling) processes, when coupling different molecules together, is to obtain such a bioconjugate (NP-fluorophore), that is stable (molecules in a complex should not comprimise each other and their functionality), reproducible and relatively easy to develop. The combination of different fluorescent NMs, their size, number, orientation, bond affinity etc. is important. One strategy is to attach different biomolecules to the NPs inbioconjugate, the other one is having the biomolecule (for example a protein) as central component and labeling it with NP-fluorophore. Nevertheless, there could be also a disadvantage in multi coupling, merely due to the binding competition between molecules (Hötzer et al. 2012).

There are few fluorescent NPs known (Hötzer et al. 2012, Ruedas-Rama et al. 2012). Some of them have been succesfully implemented into detection of pathogens and will be mentioned and discussed. The most effective target detection is achieved by using receptor-specific molecules and biomolecules, such asenzymes, antibodies, small molecules and oligonucleotides. The coupling of those biomolecules to fluorescent NP relies merely on effecient chemistry, which can be accomplished, usually by classical covalent binding (Kaittanis et al. 2010).

A real step forward in real time sensitive imaging and sensing applications have been adepted with the development of Quantum dots (QDs). QDs are crystalline materials, facet and lattice structured, analogous to the bulk semiconductor materials. The semiconductor nanocrystals bear dimension from 1-10 nm and, depending on its size, each nanocrystal can comprise lots of atoms, from which a large fraction are located at the nanocrystal surface, leading to high surfaceto-volume ratio property. Most of QDs, used for analytical applications, are synthesized as core/shell structures(GeszkeMoritz and Moritz 2013). The core part is composed of variety of substances (CdSe most common), with doping ions (such as $\mathrm{Mn}^{2+}, \mathrm{Er}^{3+}$ etc.) that improve their optical properties. The anorganic shell protects the core and improves the optical property ( $\mathrm{ZnS}$ most common). The whole structure is covered with organic, stabilizing layer. The composition of semiconductor material enables the ability to conduct electricity under only specific conditions, but not others, which make them a very good tool for the control of electrical current. Their conductance therefore varries, depending on the intensity of irradiation by infrared (IR), visible light, ultraviolet (UV), $\mathrm{X}$ rays or on the current or voltage, applied to a control electrode (Petryayeva et al. 2013). In fact, as being semiconductors, they consist of two bands, one is conduction band (high in energy), the other is valence band (low in energy) and a bandgap between them. By light excitation, an electrone transfer occurs from valence to conduction band, resulting in a hole in valence band. Due to reduced size to nanoscale dimension, high surface to volume ratio and the bandgap increment, a restriction of electron motion in specific energy levels occurs (named confinement), resulting inincreasmentor enlargement of the bandgap. Ultimately, the bandgap energy also increases. This phenomenonis known as "quantum confinement" and results in shifting of luminiscence emission wavelenght. Thus, the luminiscence wave lenght and a bandgap energy 
can be tuned by selecting an appropriate semiconductor material and a nanocrystal size. Moreover, by modulating their size, they can be excited at a given wavelenght and have simultaneously tunable emission from UV to the near IR region. QDs have also a unique property of beinghighly bright and extremely photostable. Another advantage of QDs is their long excited state lifetimes (longer than those from classical fluorescent dyes) and chemical degradation, due to the inorganic composition and the confinement effect (Petryayeva et al. 2013). Modification of QDs surface give raise to variety of conjugation strategies (mostly covalent and non-covalent), with biomolecules such as vitamin, proteins, peptides, antibodies etc.

All these properties make QDs a very suitable tool for various biomedical applications, such as sensor and detecting tool for biomarkers, pathogens, immunolabeling of cells and tissue (Kaittanis et al., 2010, Geszke-Moritz and Moritz, 2013). QDs have also emerged as promising nanomaterials for microbial detection. Liandris et al. 2011 detected pathogenic Mycobacteria with CdSe QDs, conjugated with streptavidin. Bacteria were isolated, using magnetic beads separation technique, coupled to anti-Mycobacteria antibody. Afterwards, the complex was tagged with biotynilated antibody and added to QDs, conjugated with streptavidin, resulting in detection of a fluorescent signal.

Furthermore, a rapid screening of genetic biomarkers of several infectious agents was performed using QDs barcodes (Giri et al. 2011). Barcoding technology is a molecular technolology, in which microbeads are dopped with organic dyes of different wavelenghts and intensities to create a library of barcodes for multiplex detection of target moleculesare measured. In that assay, barcodes were prepared with different emitting QDs. The obtained QDs barcodes were conjugated with single stranded oligonucleotides that can hybridize to a target sequence. The target sequence was hybridized onto an oligonucleotide, conjugated to specific dye. By introducing the target, the complex hybridomoccured, leaving the possibility of measuring its optical emission, by observing a fluorescence signal. The multicolor QDs may be used for multiplexed assay, that is, for simultaneous detection of number of pathogens in a clinical, environmental or food sample (Hahn et al. 2005). Hahn and co-workers demonstrated cca. two orders of magnitude more sensitivity (brighter signal) of streptavidin-conjugated CdSe/ZnS (core/ shell) QDs in detecting E.coli O157:H7 strain compared to normal classical dye (FITC). The binding of the target occurs through biotinylated anti-target antibody. The indirect bond between streptavidin-biotin results in detecting a complex of target-antibody-biotin-streptavidin-QDs fluorometrically.

\section{Silica NPs}

Silica (silicone dioxide) is an inorganic chemical compound, found in nature as quarz. Silica NPshave been merely used in combination with the fluorophores, which, once incorporated into silica NPs, give raise to several applications, including detection of pathogens. Silica NPs have the advantage of robust materials, mechanically stable and transparent, enabling the stabilization and protection of encapsulated flourophores. On the other hand, their optical transparency allows excitation and emission light to pass through. They show good biocompatibility, functionalization, appeared to be nontoxic (not in all cases) to the cells and can be easily prepared (Shirahata 2011). Moreover, the encapsulation into silica matrix can be performed with more than one fluorophore, resulting in brighter detection in comparison to single organic dyes (He et al. 2009). The use of silica as a NPs matrix does not alter the physical or chemical characteristics of encapsulated agent (fluorescent dye, QDs, metal NPs) (Tallury et al. 2010). Wang et al. 2007 doped silica NPs with three different dyes. The complex NPs was conjugated to the specific monoclonal antibody (streptavidine-biotin bond) against several pathogenic bacterias. A very strong flourescence signal was obtained, varying the ratio of the three fluorescence dyes, where the excitation with a single wave lenght resulted in appearance of different colours, enabling the multiple targets detection. The phenomenon is called Förster resonance energy transfer (FRET). It relies on the distant-dependent transfer of energy between two molecules, a donor, which initially absorb the energy and consequently transfer/transmit it to the other molecule, an acceptor. The distance between the two molecules matters, that is why FRET has been used to investigate molecular interactions and their distances. However, generally, FRET occurs only when the donor/acceptor molecules are in close proximity. Another attemp to increase signals for a rapid detection of $E$. coli O157:H7 was performed with fluorescent dye-doped silica NPs (Tuitemwong et al. 2013). In this assay, the silica NPs were conjugated to anti E. coli antibody after being modified with amino group, resulting in a stronger binding. Detection of the bacteria was performed with fluorescence microscope. Fluorescencent-bioconjugated silica NPs were also used in a work of Zhao et al. 2004. Each nanoparticle encapsulated thousands of fluorescent dye molecules, resulting in a highly amplified and reproducible signal. Moreover, the NPs were conjugated with antibody specific to target bacteriaE. coli O157:H7, therefore anantigen-antibody binding resulted in more sensitive detection. The assay was also applicable to water and food sample.

\section{SAFETY OF NANOTECHNOLOGY IN FOOD AND THE IMPACT ON CONSUMER'S HEALTH}

While the successful implementation of nanotechnology is important for the growth of the global economy, a possible environmental health and safety impact of NPs has to be taken in consideration. Once in the environment, NPs may undergo diverse transformations (physical, chemical, and biological), potentially altering their biological impact and outcome (Klaine et al. 2008). Different physiological conditions, such as $\mathrm{pH}$, salinity, microorganisms and natural organic matter may affect the reactivity, mobility and toxicity of NPs (Lee et al. 2010).

Ingestion, besides dermal and respiratory way, is probably the most common way of intentional exposure to various NPs. Informations about the metabolism or biotransformation of 
NPs after ingestion is relatively scarce, leading to reasonable concern about their accumulation within organs or tissues and taken up by individual cells. Moreover, they have a great ability to cross the gut wall (Chaudhry et al. 2008), they can influence on absorbtion of different molecules or havethe potential to alter body matabolism of experimental animals (Park et al. 2008).

The key determinants of the NPs functionality and their potentional adverse health effects are their physicochemical characteristics (Amini et al. 2014), their manufacturing proccess and possible interactions with body molecules (Martirosyan and Schneider 2014).

Concerning NPs physicochemical characteristics, the size is an important characteristic of NPs that should be taken in consideration. Namely, size determines the surface area of the NPs. In fact, the ultra fine urban particles $(<0.1$ micron diameter) can cause a greater inflammatory response in lungs, compared to larger particles, due to the bigger inhalated quantity (smaller particle size) Moreover, their surface property, very high size-specific deposition and their easier escape from host immunity defence may also contribute to inflammation (Oberdörster 2001). Different size of silica $\mathrm{NPs}\left(\mathrm{SiO}_{2}\right)$ may have also different toxic effects on the upper layers of the skin (mouse keratinocytes). The study of Yu et al. 2008 have demonstrated that particles below $100 \mathrm{~nm}$ induce cytotoxicity. Moreover, the concentration of silica NPs also matters. In fact, $<20 \mu \mathrm{g} / \mathrm{mL}$ is supposed to be safe, regarding lung toxicity. However, there are discrepancy in hepatoxicological effects of silica NPs. In relation tosize and concentrations dependent toxicity, gold NPs have been also studied and are generally considered safe, as being in routine clinical use for many years. However, a lot of contradictory results, especially regarding skin toxicology issues, could be found (Yildirimer et al. 2011).

The chemical composition of NPs plays also an important role. The potential toxicity of the chemical composition of NPs may not be directly connected to the chemical structure of the NPs, but rather to their remains (impurities, reagents) orprocentageof them in the final products. For instance, Murray et al. 2009 proved the toxic effects of impurities (30\% of iron) in single-walled carbon nanotubes on the skin in one mouse model. However, no negative toxic effects in samples with $0,23 \%$ of detected iron impurities were observed. One study examined the role of different size and crystallinity oftitanium dioxide $\left(\mathrm{TiO}_{2}\right)$ NPs (merely used in cosmetics, as UV filters for example) in inducing different cytotoxical effects in vitro (Braydich-Stolle et al. 2008).

Furthermore, the lower the degradability and solubility of NPs is, the higher the NPs deposition in different tissues may occur (Borm and Kreyling 2004). Moreover, insoluble particles mayalso accumulate in different organs. Nevertheless, $\mathrm{TiO}_{2}$ is reported to be more toxical in soluble (hydrofilic) than in insoluble state (Oberdörster 2001). The toxicity of the oxide NPs of different composition, but similar size (regarding their effects on living cells) at concentrations ranging from 0 to $30 \mathrm{ppm}$, have also been published, suggesting again, that the solubility plays an important role in toxicity of the NPs (Brunner et al. 2006).

Because of the big surface structure, NPs can, once absorbed in the body, interact with many biomolecules (functionalization). In fact, the properties like hydrophobicity, surface charge and chemistry may influence their toxicological effects. For instance, positively charged silver NPs are more toxic as negatively charged, a property that has to be taken more in consideration as their size and shape (El Badawy et al. 2011). Thus, modification of the surface of NPs is very important in terms of toxicological effects, once NPs are absorbed in human body. A good example of that are NPs, used in drug delivery such as magnetic NPs. In one work, magnetic NPs were coated with polymeric polyethylene glycol (PEG), which supposedly decreased the toxic effects of bare particles (Gupta and Wells 2004). Nevertheless, magnetic NPs are physiologically well tolerated, especially those with largerly hydrophobic surface. Due to that, once they are in circulation, they are attracted to plasma proteins faster than those with hydrofilic surface, resulting in coating process, known as opsonisation, and thus, causing their rapid removal from the circulation (Berry and Curtis 2003). The importancy in coating the core to reduce toxicity (especially in liver), due to degradation protection, has been investigated a lot in QDs. Moreover, the main reported toxicological effects of QDs are due to inadequate core covarage or inapropriate material coating (Yildirimer et al. 2011).

Taking the whole food chain concept, Magnuson et al. 2011 proposed 3 most popular areas, where the exposure to nanomaterials could mostly come from: direct addition (nano encapsulation of ingredients, antimicrobials), food manufacturing, processing and preservation and contamination (NPs from other industries released in the environment or watter supply). Among all the exposed materials, the metal (silver) / metal oxide NPs have the highest potentiality to be ingested, due to their increasing inclusion in dietary supplements and food conservation materials (reviewed in Martirosyan and Schneider 2014).

Many informations and evidence about potential side effects of NPs are rising, including their influence ongastrointestinal tract, their immunomodulatory effect, alternation incell development and growth process, disruption of endocrine system and influence on the reproductive health (reviewed in Martirosyan and Schneider 2014). Moreover, there is an evidence, that NPs may induce epigenetic changes through DNA methylation, histone modifications and RNA interference (Smolkova et al. 2015).

Nevertheless, there is no justifying evidence and no general conclusion, whether the food or food contact materials, derived from nanotechnology are either safe or dangerous (Martirosyan and Schneider 2014).

\section{CONCLUSIONS}

The biggest challenge for the detection of pathogen bacteria is to develop fast and cost effective methods to exceed the sensitivity of conventional approaches. The significant advancements in the field of molecular biology and nanotechnology have made in this regard remarkable breakthroughs in the area of microbial diagnosis and identification. Development of detection methods with sensitivity, selectivity, and speediness is urgently required for screening, due to their occurence in diagnosing 
diseases, caused by foodborne pathogens. Implementing nanotechnology properties into biosensors is one step forward to efficient and successful detection of microbials in different food and environmental samples.

Despite the enormous success in field of detection of pathogen microorganisms, nanotechnology has so far many gaps in understanding the metabolism and biotransformation in case of exposure or ingestion of NPs. There is a need of a proper systematic categorization and classification of NPs, leading to a better evaluation of their biological effects andpotentional impact (acute or chronic) on the consumer's health. Furthermore, more development of specific methods and models for evaluation of the potentional toxicity in some nanostructure materialsis needed. Moreover, the legal regulation of NMs in food sector has still many gaps, which need to be clarified. Regarding epigenetic effects of NPs, more standarized assays and analytical approaches should be taken in consideration, as potential effects could leave catastrophic consequences on the miniature level of our nucleic acids.

\section{REFERENCES}

1. Agasti SS, Rana S, Park M-H, Kim CK, You C-C, Rotello VM. Nanoparticles for detection and diagnosis. Adv. Drug Deliv. Rev. 2010; 62:316-28.

2. Ali MA. Detection of E.coli O157:H7 in feed samples using gold nanoparticles sensor. Int.J.Curr.Microbiol. App.Sci. 2014;697-708.

3. Amini SM, Gilaki M, Karchani M. Safety of nanotechnology in food industries. Electron. physician.2014;6:962-8.

4. Arora P, Sindhu A, Dilbaghi N, Chaudhury A. Biosensors as innovative tools for the detection of food borne pathogens. Biosens. Bioelectron. 2011;28:1-12.

5. El Badawy AM, Silva RG, Morris B, Scheckel KG, Suidan MT, Tolaymat TM. Surface charge-dependent toxicity of silver nanoparticles. Environ. Sci. Technol. 2011;45:283-7.

6. Berry CC, Curtis ASG. Functionalisation of magnetic nanoparticles for applications in biomedicine. J. Phys. D. Appl. Phys.2003;36:R198-R206.

7. Billington C, Hudson JA, D'Sa E. Prevention of bacterial foodborne disease using nanobiotechnology. Nanotechnol. Sci. Appl. 2014;7:73-83.

8. Boehm DA, Gottlieb PA, Hua SZ. On-chip microfluidic biosensor for bacterial detection and identification. Sensors Actuators B Chem. 2007;126:508-14.

9. Bolhassani A, Javanzad S, Saleh T, Hashemi M, Aghasadeghi MR, Sadat SM. Polymeric nanoparticles: potent vectors for vaccine delivery targeting cancer and infectious diseases. Hum. Vaccin. Immunother. 2014;10:321-32.

10. Borm PJA, Kreyling W. Toxicological hazards of inhaled nanoparticles--potential implications for drug delivery. J. Nanosci. Nanotechnol. 2004;4:521-31.

11. Braydich-Stolle LK, Schaeublin NM, Murdock RC, Jiang J, Biswas P, Schlager JJ, Hussain SM. Crystal structure mediates mode of cell death in $\mathrm{TiO}_{2}$ nanotoxicity. J. Nanoparticle Res. 2008;11:1361-74.

12. Brunner TJ, Wick P, Manser P, Spohn P, Grass RN, Limbach LK, Bruinink A, Stark WJ. In vitro cytotoxicity of oxide nanoparticles: comparison to asbestos, silica, and the effect of particle solubility. Environ. Sci. Technol. 2006;40:4374-81.

13. Chaudhry Q, Scotter M, Blackburn J, Ross B, Boxall A, Castle L, Aitken R, Watkins R. Applications and implications of nanotechnologies for the food sector. Food Addit. Contam. Part A. Chem. Anal. Control. Expo. Risk Assess. 2008;25:241-58.

14. Chen Z, Mauk MG, Wang J, Abrams WR, Corstjens PL, Niedbala RS, Malamud D, Bau HH. A microfluidic system for saliva-based detection of infectious diseases. Ann. N. Y. Acad. Sci. 2007;1098:429-36.

15. Chung MS, Kim CM, Ha SD. Detection and enumeration of microorganisms in ready-to-eat foods, ready-tocook foods and fresh-cut produce in Korea. J. Food Saf. 2010;30:480-89.

16. Cui S, Zhou S, Chen C, Qi T, Zhang C, Oh J.. A simple and rapid immunochromatographic strip test for detecting antibody to porcine reproductive and respiratory syndrome virus. J. Virol. Methods.2008;152:38-42.

17. Doria G, Conde J, Veigas B, Giestas L, Almeida C, Assunção M, João R, Pedro VB. Noble metal nanoparticles for biosensing applications. Sensors (Basel). 2012;12:165787.

18. Dutse SW, Yusof NA. Microfluidics-based lab-on-chip systems in DNA-based biosensing: an overview. Sensors (Basel). 2011;11:5754-68.

19. Gabig-Ciminska M. Developing nucleic acid-based electrical detection systems. Microb. Cell Fact. 2006;5:9.

20. Geszke-Moritz M, Moritz M. Quantum dots as versatile probes in medical sciences: synthesis, modification and properties. Mater. Sci. Eng. C. Mater. Biol. Appl. 2013;33:1008-21.

21. Gill P, Alvandi A-H, Abdul-Tehrani H, Sadeghizadeh M. Colorimetric detection of Helicobacter pylori DNA using isothermal helicase-dependent amplification and gold nanoparticle probes. Diagn. Microbiol. Infect. Dis. 2008;62:119-24.

22. Giri S, Sykes EA, Jennings TL, Chan WCW. Rapid screening of genetic biomarkers of infectious agents using quantum dot barcodes. ACS Nano. 2011;5:1580-7.

23. Gupta AK, Gupta M. Synthesis and surface engineering of iron oxide nanoparticles for biomedical applications. Biomaterials. 2005;26:3995-4021.

24. Gupta AK, Wells S. Surface-Modified Superparamagnetic Nanoparticles for Drug Delivery: Preparation, Characterization, and Cytotoxicity Studies. IEEE Trans. Nanobioscience. 2004;3:66-73.

25. Hahn MA, Tabb JS, Krauss TD. Detection of single bacterial pathogens with semiconductor quantum dots. Anal. Chem. 2005;77:4861-9.

26. Halfpenny KC, Wright DW. Nanoparticle detection of respiratory infection. Wiley Interdiscip. Rev. Nanomed. Nanobiotechnol. 2010;2:277-90.

27. He Y, Kang Z-H, Li Q-S, Tsang CHA, Fan C-H, Lee S-T. Ultrastable, highly fluorescent, and water-dispersed silicon-based nanospheres as cellular probes. Angew. Chem. Int. Ed. Engl. 2009;48:128-32.

28. Hötzer B, Medintz IL, Hildebrandt N. Fluorescence in nanobiotechnology: sophisticated fluorophores for novel applications. Small. 2012;8:2297-326. 
29. Huang SH. Gold nanoparticle-based immunochromatographic test for identification of Staphylococcus aureus from clinical specimens. Clin. Chim. Acta. 2006;373:139-43.

30. Huang YF, Wang YF, Yan XP. Amine-functionalized magnetic nanoparticles for rapid capture and removal of bacterial pathogens. Environ. Sci. Technol. 2010;44:790813.

31. Jain KK. Applications of nanobiotechnology in clinical diagnostics. Clin. Chem. 2007;53:2002-9.

32. Kaittanis C, Naser SA, Perez JM. One-step, nanoparticlemediated bacterial detection with magnetic relaxation. Nano Lett. 2007;7:380-3.

33. Kaittanis C, Nath S, Perez JM. Rapid nanoparticlemediated monitoring of bacterial metabolic activity and assessment of antimicrobial susceptibility in blood with magnetic relaxation. PLoS One. 2008;3:e3253.

34. Kaittanis C, Santra S, Perez JM. Emerging nanotechnologybased strategies for the identification of microbial pathogenesis. Adv. Drug Deliv. Rev. 2010;62:408-23.

35. Kalpana Sastry R, Anshul S, Rao NH. Nanotechnology in food processing sector-An assessment of emerging trends. J. Food Sci. Technol. 2013;50:831-41.

36. Karimi Z, Karimi L, Shokrollahi H. Nano-magnetic particles used in biomedicine: core and coating materials. Mater. Sci. Eng. C. Mater. Biol. Appl. 2013;33:2465-75.

37. Kim BYS, Rutka JT, Chan WCW. Nanomedicine. N. Engl. J. Med. 2010;363:2434-43.

38. Kim G, Moon J-H, Moh C-Y, Lim J. A microfluidic nanobiosensor for the detection of pathogenic Salmonella. Biosens. Bioelectron. 2015;67:243-7.

39. Klaine SJ, Alvarez PJJ, Batley GE, Fernandes TF, Handy RD, Lyon DY, Mahendra S, McLaughlin MJ, Lead JR.Nanomaterials in the environment: behavior, fate, bioavailability, and effects. Environ. Toxicol. Chem. 2008;27:1825.

40. Koedrith P, Thasiphu T, Weon J-I, Boonprasert R, Tuitemwong K, Tuitemwong $\mathrm{P}$. Recent trends in rapid environmental monitoring of pathogens and toxicants: potential of nanoparticle-based biosensor and applications. ScientificWorldJournal. 2015;2015:510982.

41. Koh I, Josephson L. Magnetic nanoparticle sensors. Sensors (Basel). 2009;9:8130-45.

42. Law JW-F, Ab Mutalib N-S, Chan K-G, Lee L-H. Rapid methods for the detection of foodborne bacterial pathogens: principles, applications, advantages and limitations. Front. Microbiol. 2014;5:770.

43. Lee H, Yoon T-J, Weissleder R. Ultrasensitive detection of bacteria using core-shell nanoparticles and an NMR-filter system. Angew. Chem. Int. Ed. Engl. 2009; 48:5657-60.

44. Lee J, Mahendra S, Alvarez PJJ. Nanomaterials in the construction industry: a review of their applications and environmental health and safety considerations. ACS Nano 2010;4:3580-90.

45. Lee N, Kwon KY, Oh SK, Chang H-J, Chun HS, Choi S-W. A multiplex PCR assay for simultaneous detection of Escherichia coli O157:H7, Bacillus cereus, Vibrio parahaemolyticus, Salmonella spp., Listeria monocytogenes, and Staphylococcus aureus in Korean ready-to-eat food. Foodborne Pathog. Dis. 2014;11:574-
80.

46. Levitt MH. Spin Dynamics: Basics of Nuclear Magnetic Resonance, 2nd Edition - Malcolm H. Levitt. Wiley. 2008;740.

47. Liandris E, Gazouli M, Andreadou M, Sechi LA, Rosu V, Ikonomopoulos J. Detection of pathogenic mycobacteria based on functionalized quantum dots coupled with immunomagnetic separation. PLoS One. 2011;6:e20026.

48. Liao JY, Song Y, Liu Y. A new trend to determine biochemical parameters by quantitative FRET assays. Acta Pharm. Sinic. 2015;36:1408-15.

49. LIU R, MUNRO S, NGUYEN T, SIUDA T, SUCIU D, BIZAK M,SLOTA M, FUJI HS, DANLEY D, McSHEA A. Integrated Microfluidic CustomArray Device for Bacterial Genotyping and Identification. J. Assoc. Lab. Autom. 2006;11:360-367.

50. Liu WT. Nanoparticles and their biological and environmental applications. J. Biosci. Bioeng. 2006;102:1-7.

51. Liz-Marzán LM. Tailoring surface plasmons through the morphology and assembly of metal nanoparticles. Langmuir 2006;22:32-41.

52. Maalouf R, Hassen WM, Fournier-Wirth C, Coste J, Jaffrezic-Renault N. Comparison of two innovatives approaches for bacterial detection: paramagnetic nanoparticles and self-assembled multilayer processes. Microchim. Acta 2008;163:157-161.

53. Magnuson BA, Jonaitis TS, Card JW. A brief review of the occurrence, use, and safety of food-related nanomaterials. J. Food Sci. 2011;76:R126-33.

54. Mairhofer J, Roppert K, Ertl P. Microfluidic systems for pathogen sensing: a review. Sensors (Basel). 2009;9:480423.

55. Mandal PK, Biswas AK, Choi K PU. Methods for Rapid Detection of Foodborne Pathogens: An Overview. Amer j Food. technol. 2011;87-102.

56. Martirosyan A, Schneider Y-J. Engineered nanomaterials in food: implications for food safety and consumer health. Int. J. Environ. Res. Public Health.2014;11:5720-50.

57. Murray AR, Kisin E, Leonard SS, Young SH, Kommineni C, Kagan VE, Castranova V, Shvedova AA. Oxidative stress and inflammatory response in dermal toxicity of singlewalled carbon nanotubes. Toxicology. 2009;257:161-71.

58. Oberdörster G. Pulmonary effects of inhaled ultrafine particles. Int. Arch. Occup. Environ. Health. 2001;74:1-8.

59. Oh WK, Jeong YS, Song J, Jang J. Fluorescent europiummodified polymer nanoparticles for rapid and sensitive anthrax sensors. Biosens. Bioelectron. 2011;29:172-7.

60. Oliver SP, Jayarao BM, Almeida RA. Foodborne pathogens in milk and the dairy farm environment: food safety and public health implications. Foodborne Pathog. Dis. 2005;2:115-29.

61. Omurtag I, Paulsen P, Hilbert F, Smulders FJM.The risk of transfer of foodborne bacterial hazards in Turkey through the consumption of meat; risk ranking of muscle foods with the potential to transfer Campylobacter spp. Food Secur. 2013;5:117-27.

62. Pankhurst QA, Connolly J, Jones SK, Dobson J. Applications of magnetic nanoparticles in biomedicine. J. 
Phys. D. Appl. Phys. 2003;36:R167-R181.

63. Park HS, Ahn J, Kwak HS. Effect of nano-calciumenriched milk on calcium metabolism in ovariectomized rats. J. Med. Food. 2008;11:454-9.

64. Peng F, Wang Z, Zhang S, Wu R, Hu S, Li Z, Wang X, Bi D. Development of an immunochromatographic strip for rapid detection of $\mathrm{H} 9$ subtype avian influenza viruses. Clin. Vaccine Immunol. 2008;15:569-74.

65. Petryayeva E, Algar WR, Medintz IL. Quantum dots in bioanalysis: a review of applications across various platforms for fluorescence spectroscopy and imaging. Appl. Spectrosc. 2013;67:215-52.

66. Ray PC, Darbha GK, Ray A, Walker J, Hardy W.Gold Nanoparticle Based FRET for DNA Detection. Plasmonics. 2007;2:173-83.

67. Rosec JP, Causse V, Cruz B, Rauzier J, Carnat L. The international standard ISO/TS 21872-1 to study the occurence of totaland pathogenic Vibrioparahaemolyticus and Vibrio cholerae in seafood: ITS improvement by use of a chromogenic medium and PCR. Int. J. Food Microbiol. 2012;157:189-94.

68. Rosi NL, Mirkin CA. Nanostructures in biodiagnostics. Chem. Rev. 2005; 105:1547-62.

69. Ruedas-Rama MJ, Walters JD, Orte A, Hall EAH. Fluorescent nanoparticles for intracellular sensing: a review. Anal. Chim. Acta. 2012;751:1-23.

70. Shah M, Badwaik V, Kherde Y, Waghwani HK, Modi T, Aguilar ZP, Rodgers H, Hamilton W, Marutharaj T, Webb C, Lawrenz MB, Dakshinamurthy R. Gold nanoparticles: various methods of synthesis and antibacterial applications. Front. Biosci. Landmark Ed. 2014;19:132044.

71. Shirahata N. Colloidal Si nanocrystals: a controlled organic-inorganic interface and its implications of color-tuning and chemical design toward sophisticated architectures. Phys. Chem. Chem. Phys. 2011;13:728494.

72. Shokrollahi H. Structure, synthetic methods, magnetic properties and biomedical applications of ferrofluids. Mater. Sci. Eng. C. Mater. Biol. Appl. 2013;33:2476-87.

73. Smolkova B, El Yamani N, Collins AR, Gutleb AC, Dusinska M. Nanoparticles in food. Epigenetic changes induced by nanomaterials and possible impact on health. Food Chem. Toxicol. 2015;77:64-73.

74. Sperling RA, Rivera Gil P, Zhang F, Zanella M, Parak WJ. Biological applications of gold nanoparticles. Chem. Soc. Rev. 2008;37:1896-908.

75. Syed MA, Bokhari SHA. Gold Nanoparticle Based Microbial Detection and Identification. J. Biomed. Nanotechnol. 2011;7:229-37.

76. Syed MA. Advances in nanodiagnostic techniques for microbial agents. Biosens. Bioelectron. 2014;51:391-400.

77. TalluryP, Malhotra A,ByrneLM,SantraS. Nanobioimaging and sensing of infectious diseases. Adv. Drug Deliv. Rev. 2010;62:424-37.

78. Tartaj P, Morales M a del P, Veintemillas-Verdaguer S, Gonz lez-Carre o T, Serna CJ. The preparation of magnetic nanoparticles for applications in biomedicine. J. Phys. D. Appl. Phys. 2003;36:R182-R197.

79. Thakur MS, Ragavan K V. Biosensors in food processing.
J. Food Sci. Technol. 2013;50:625-41.

80. Tuitemwong P, Songvorawit N, Tuitemwong K. Facile and Sensitive Epifluorescent Silica Nanoparticles for the Rapid Screening of EHEC. J. Nanomater. 2013; 2013:1-8.

81. Varshney M, Li Y. Interdigitated array microelectrode based impedance biosensor coupled with magnetic nanoparticle-antibody conjugates for detection of Escherichia coli O157:H7 in food samples. Biosens. Bioelectron. 2007;22:2408-14.

82. Vashist SK. Nanomaterials-Based Health Care and Bioanalytical Applications: Trend and Prospects. Nanomater. Mol. Nanotechnol. 2013;2:2.

83. Wang L, Ma W, Xu L, Chen W, Zhu Y, Xu C, Kotov NA. Nanoparticle-based environmental sensors. Mater. Sci. Eng. R Reports 2010;70:265-74.

84. Wang L, Zhao W, O’Donoghue MB, Tan W. Fluorescent nanoparticles for multiplexed bacteria monitoring. Bioconjug. Chem. 2007;18:297-301.

85. Wingstrand A, Neimann J, Engberg J, Nielsen EM, Gerner-Smidt P, Wegener HC, Mølbak K. Fresh chicken as main risk factor for campylobacteriosis. Denmark. Emerg. Infect. Dis. 2006;12:280-5.

86. $\mathrm{Xu} \mathrm{C}$, Sun S. New forms of superparamagnetic nanoparticles for biomedical applications. Adv. Drug Deliv. Rev. 2013;65:732-43.

87. Yeh YC, Creran B, Rotello VM. Gold nanoparticles: preparation, properties, and applications in bionanotechnology. Nanoscale. 2012;4:1871-80.

88. Yildirimer L, Thanh NTK, Loizidou M, Seifalian AM. Toxicology and clinical potential of nanoparticles. Nano Today. 2011;6:585-607.

89. Yu KO, Grabinski CM, Schrand AM, Murdock RC, Wang W, Gu B, Schlager JJ, HussainSM. Toxicity of amorphous silica nanoparticles in mouse keratinocytes. J. Nanoparticle Res. 2008;11:15-24.

90. Zhang G. Foodborne Pathogenic Bacteria Detection: An Evaluation of Current and Developing Methods. The Meducator 2013.1.

91. Zhang Y. Electrochemical DNA Biosensors Based on Gold Nanoparticles / Cysteamine / Poly(glutamic acid) Modified Electrode. Am. J. Biomed. Sci. 2007;115.

92. Zhao X, Hilliard LR, Mechery SJ, Wang Y, Bagwe RP, Jin S, Tan W. A rapid bioassay for single bacterial cell quantitation using bioconjugated nanoparticles. Proc. Natl. Acad. Sci. U. S. A. 2004;101:15027-32.

93. Zhao X, Lin C-W, Wang J, Oh DH. Advances in rapid detection methods for foodborne pathogens. J. Microbiol. Biotechnol. 2014;24:297-312. 


\section{Nanotehnologija na področju varnosti hrane in ocenjevanja kakovosti: potencialnost nanodelcev $\mathbf{v}$ diagnostiki prehranskih povzročiteljev bolezni}

\section{IZVLEČEK}

Ključ do preprečevanja številnih bolezni, povzročenih z uživanjem kontaminirane hrane, sloni na hitrem odkrivanju mikrobov v različnem biološkem in okoljskem materialu. Uporaba nanotehnologije na področju varnosti hrane predstavlja velik korak v smeri uspešnih, zanesljivih in občutljivih metod za odkrivanje prehranskih povzročiteljev bolezni. Cilj preglednega članka je predstaviti nekatere glavne značilnosti nanotehnološko-baziranih tehnik, uporabljenih za odkrivanje mikrobov v zadnjih letih. Prav tako se pregledni članek dotakne vprašanja o varnosti uporabe nanomaterialov, predvsem z vidika potrošnikovega zdravja. Nanomateriali se, zaradi njihove različne sestave, ponašajo z edinstvenimi lastnostmi kot so večja prepustnost in prodornost, odzivnost ter večje razmerje površine v odvisnosti od volumna. Njihova sposobnost vezave na številne biomolekule in integriranje v posebne sistemske naprave pripomore k izboljšanju občutljivosti prenašanja bioloških signalnih informacij v krajšem časovnem intervalu. Široka uporaba zlatih, magnetnih in fluorescentnih nanodelcev je znana tudi v mikrobni diagnostiki. Kljub uspehu povezovanja nanotehnologije z odkrivanjem prehranskih povzročiteljev bolezni, je zaključek o tem ali izpostavljenost nanomaterialom pomeni potencialno tveganje za zdravje ljudi, potrebno še dokazati.

Ključne besede: nanotehnologija, varnost hrane, nanodelci, diagnostika, prehranski povzročitelji bolezni 